\title{
Implementing Sustainable Thinking and Acting into Design- and Textile Education-A Holistic and Interdisciplinary Learning Model
}

\author{
Carolin Ermer* \\ Germany \\ *Corresponding author: Carolin Ermer, Germany
}

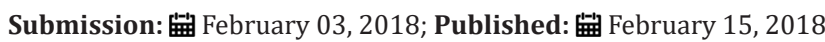

\section{Introduction}

The textile and clothing industry in Germany is the second largest consumer goods industry after the food industry with an annual turnover of 27 billion Euros (see BMWI 2017). Germans buy an average of about $28 \mathrm{~kg}$ of textiles per year and it gets more and more [1]. In the course of this development of the associated socalled "fast fashion", the clothing industry is increasingly becoming involved in innumerable ecological, economic and social grievances and disasters in the countries of manufacture. Such as, for example, the collapse of the Rana Plaza in 2013 in Bangladesh, which killed over 1,000 people and injured more than 2,000 [2]. The Clean Clothes Campaign (CCC) describes this event as "the worst ever industrial accident to hit the garment industry" (Ibid. 2016). Although awareness slowly raises at the moment sustainability issues still don't get the urgently needed attention by the textile industry, since products are designed to enable quick profit, concepts of sustainable consumption are seen as non-profitable for business and production chain. On the other hand, "it is estimated that the product design and development phase carries approximately $80 \%$ or even more of the environmental and social impacts of the product including the manufacturing, use and disposal phase" [3]. For a radical change of the existing system towards a more sustainable, a paradigm shift towards new mindsets is needed [4]. Hence the importance of designers and textile technicians at the beginning of the textile chainand within thata modification of their education is becoming more and more important. "Designers have a key role in creating more opportunities for sustainable consumption and production" [5].

\section{Objectives}

The course concept "sustainable textiles and fashion design" was first established in 2016 at the University of Applied Sciences in Berlin (HTW Berlin, Germany) and aims to create a space, where design and textile engineering students can meet and collaborate with other mostly non-textile related but fashion-interested professions to create innovative and future-oriented attempts concerning the non-sustainable business of the textile industry.

Design theorist Victor Margolin sees a change of role of designers facing the challenges of our time. They no longer are just "stylists" of products that are consumed, but rather can take the possibility to assume the role of a mediator. As creators of models, prototypes, and propositions, designers occupy a dialectical space between the existing world and the world that could be. Informed by the past and present, their activity is oriented toward the future. They operate in situations that call for interventions, and they have the unique ability to intervene in material and immaterial forms [6]. Based on the current situation in the clothing industry described in the introduction, it is therefore important to start at the source of the problem. This means familiarizing future fashion designers (and textile engineers as well) with sustainable thinking and the possibilities of sustainable action that comes within their studies.

The interdisciplinary and project-based course "sustainable textiles and fashion design" is invented based onan intensive literature research in education for sustainable development (ESD) and an evaluation of three different international teaching case studies for sustainable fashion design [7]. In regard of the related research concerning competences for ESD as well as of the comparison of the case studies in fashion design education, the fields of self-competence and social competence so called social skills play a major role. They are able to support an enhancement of sustainable thinking and acting. The technical and methodological competencies are also considered important, but are by no means more important than social skills. In areas, ESD as well as sustainable design education, there is a broad agreement about sustainable development as a successful interaction of all fields of competence within the appropriate forms and fields of learning [813].

\section{Fields of learning for sustainable design education}

For a future theory practice transfer and competence enhancement through sustainable fashion design education, the research study developed four supportive different learning fields [7]. In detail these are: 


\section{Ecological literacy\& sustainable design-enhancing professional} competence and social skills:

i. Understand and reflect on socio-cultural, environmental and economic aspects of sustainability issues within the context

ii. Understand sustainability and sustainable design strategies as a necessary external framework for designing design / fashion design and apparel production

iii. Acquisition of expertise and strategies along the textile chain

iv. Acquisition of innovative knowledge and promotion of innovative ideas and their implementation

Collaborative learning \& social learning - enhancing social skills and self-competence:

i. Project work as a particularly suitable form of learning for the sustainable context

\section{ii. High theory-practice transfer}

iii. Group work, where each participant is equal and all decisions are made together

iv. Innovative learning concepts, such as "Work local" (working within local projects and for the community and learning)

v. Encourage co-creating of designers with factory workers and customers

vi. Promote ethical and social action

vii. High process orientation

Interdisciplinary \& transdisciplinary learning - enhancing social skills and self-competence:

i. Cooperation in study teams with different disciplines

ii. Cooperation between business and research

iii. Co-creation of study content with students

iv. Cooperation with different stakeholders in the textile industry

v. Experience new learning spaces outside the classroom, "Reality Modeling"

\section{Critical thinking \& mindfulness enhancing self-competence:}

i. Learn Systemic and Critical Thinking

ii. Critically reflecting on and analyzing one's own actions and thoughts and the projects / results worked out

iii. Take a meta-level: Reflect on your own learning process

iv. Developing a new and new value system apart from the industrial specifications for design and fashion

v. Strengthen innovation thinking and forward thinking

\section{Suggestion for a didactic methodical model}

The specified four fields of learning can be combined in a didactic-methodical model for implementation into practice.
They are closely connected as well as depending on each other. Although there are more fields of learning for ESD, it consists of a deliberate reduction of learning fields. This is intended to counteract the excessive demands of teachers as well as students, which has repeatedly been described as an obstacle to learning within a sustainability context $[12,14]$. The proposal is also particularly suitable for design courses, since the relevance of applied learning techniques here is of great importance and unlike in many other disciplines already exists. Project based learning and working is known and usually accepted. However, social and collaborative learning should in any case be introduced and promoted thoroughly within this special learning context in order to raise awareness of project work as a beneficial cooperation for all participants. As the research in the examined case studies has shown, this does not come about by itself, but has to be stimulated and actively supported by teachers (Figure 1).

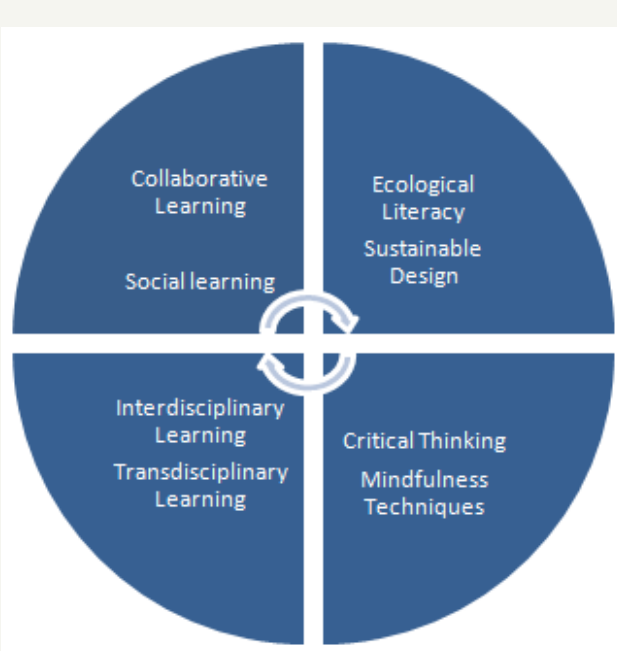

Figure 1: Model of learning forms and fields for a didacticmethodical concept [7].

\section{Evaluation}

It is evident that interdisciplinary and collaborative learning supports personal and social competencies [15]. It also serves as fundamental to group-based learning, where innovative and "outof-the-box" ideas can evolve and critical discussions can happen. Evaluation of the course concept shows that students appreciate the open, self-monitored and divers learning environment. Over $80 \%$ of the students where highly engaged in their projects and were able to realize their own innovative ideas. Although getting deeper into the negative aspects and topics of the existing fashion industry, students are sometimes facing difficulties to stay focused on the positive and "change maker" aspects of their work $[7,12]$. During the different project stages there can be phases where some students feel helpless facing the huge amount of problems in the industry. Regarding topics of sustainable development, it is essential for teachers to stay close to students during the different learning phases and point out more towards positive examples and possibilities for a change. To question and develop their own beliefs and mindsets techniques like critical thinking and mindfulness methods can be supportive. 
In our fast and overly-connected world value of information has never been as obsolescent as it is today and staying focused and clear is one of the big issues in our life $[9,16]$. Integrating mindfulness aspects into ESD and education for sustainable consumption as a tool to raise awareness and action is highly discussed in different areas of scientific research at the moment [17]. Next to professional input like ecological literacy [18] and the evident sustainable design strategies like "zero waste", "re/ up cycling" and "circular design" [17] students therefore also gain a basic understanding about mindfulness as well as critical thinking throughout the course. These tools are provided not only as subject for their studies, but also to develop a self-reflected and emancipatory view on the world they live in and on their own behavior. Mindfulness techniques combined with critical thinking encourages a new mindset. The combination supports staying focused and clear. Furthermore critical thinking helps to develop and strengthen students own beliefs $[7,12]$. The holistic idea behind these elements is first to learn acting mindful towards one's own habits and feelings. Students are seen with all their feelings and personal experiences. Out of that perspective thinking and acting mindful towards environmental issues as the next step seems comprehensible. The evaluation of the course concept shows that students were highly motivated to start integrating simple mindfulness techniques in their everyday life. About $85 \%$ of the students are easily engaging into different kind of mindfulness techniques during the course [7].

It is notable, that the groups of students collaborating during the semester are highly divers. They are residents of HTW and visiting student's first-year to master - of subjects as diverse as textile technology, IT, fashion design, management, textile design and communications design. Hence within group projects there is a valuable amount of divers knowledge related to individual backgrounds and competencies. Results of the projects are for example a change strategy and business plan for an existing nonsustainable company. It can be the design of a platform, where business and consumers meet and gather informationor an app that tries to connect the consumer emotionally to their clothes for an extended use of garment (Figure $1 \& 2$ ).

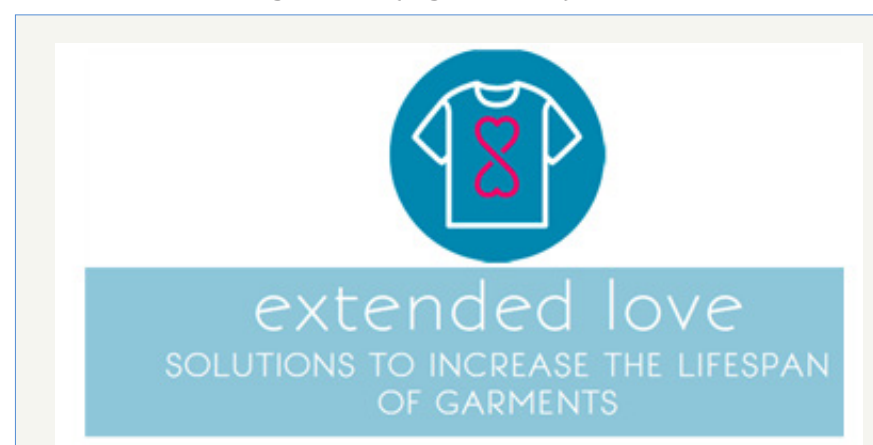

Figure 2: Front page of students app-project: "extended love", $2017 / 18$.

\section{Results}

Based on the results of the evaluation of the course and the under pinning research study, successful learning about sustainability is a mix of fields that enables a constant change of different competence requirements, different learning situations and a high relation to the learners' own requirements. This allows the highest possible potential on students' own experiences within their learning process. Students perceive a holistic vision of learning - as well as of the subject of sustainability.

The invented holistic learning model can serve as a basis for developing fashion design and textile engineering education in sustainability. Next to professional topics it also communicates an awareness of us as part of our ecosystem, the world we live in and other systems, such as surrounding social systems as well [15] for the overall goal of a functioning global cooperation and for joint future solutions in sense of a "sustainability as flourishing" [16].

The evaluation of the course as well as the study have shown that success of the projects for the implementation of sustainable thinking and acting depends not only on the high commitment of the teachers but also on innovative and divers teaching arrangements that take place outside of traditional learning spaces. In these arrangements thought and action patterns of the participants are actually dealt with seriously [19]. It is essential to focus more on the design of learning arrangements with the inclusion of the discussed fields of competence. First and foremost, these holistic learning movements focus on the individual as with its own objective experiences, opinions, attitudes, values, feelings and competences. Tomorrow's teaching concepts for design education need to take greater account of this and consider the psychological perspective of the learner in order to actually initiate real transformative learning processes.

\section{References}

1. Umweltbundesamt (2017) Gemeinsame pressemitteilung von umweltbundesamt und öko-institut e.v. faktencheck obsoleszenz.

2. Rana Plaza (2014) Clean clothes campaign.

3. Charter M, Tischner U (2001) Sustainable product design. In: Charter M, Tischner U (Eds.), Sustainable solutions: developing products and services for the future. Sheffield, England, p. 120.

4. Niinimäki K, Hassi L (2011) Emerging design strategies in sustainable production and consumption of textiles and clothing. Journal of Cleaner Production 19(16): 1876-1883.

5. Parker L (2009) Sustainable fashion: A handbook for educators. Fashioning an Ethical Industry. Bristol, England, p. 14.

6. Margolin V (2007) Design and the future of the human spirit. Design Issues 23(3): 4 .

7. Ermer C (2018) Implementierung von nachhaltigem denken und handeln in textil- und designstudiengänge. Kompetenzanforderungen und Umsetzungsvorschläge. Verlag Dr. Kovac Gmbh, Hamburg.

8. de Haan G (2008) Gestaltungskompetenz als Kompetenzkonzept für Bildung für nachhaltige Entwicklung. In: Bormann I, de Haan G (Eds.): Kompetenzen der Bildung für nachhaltige Entwicklung. Operationalisierung, Messung, Rahmenbedingungen, Befunde. Wiesbaden, Germany, pp. 23-44.

9. Wals AEJ (2011) Learning our way to sustainability. Journal of Education for Sustainable Development 5(2): 177-186.

10. Rieckmann M (2016) Kompetenzentwicklungsprozesse in der bildung für nachhaltige entwicklung erfassen-überblick über ein heterogenes forschungsfeld. In: Barth M, Rieckmann M (Eds.), Empirische Forschung 
zur bildung für nachhaltige entwicklung - themen, methoden und trends. Leverkusen, Germany, pp. 89-109.

11. Grose L (2013) Fashion design education for sustainability practice: Reflections on undergraduate level teaching. In: Gardetti MA, Torres AL (Eds.), Sustainability in fashion and textiles. Values, Design, Production and Consumption, pp. 134-147.

12. Armstrong CM, LeHew M (2013) A case study in sustainability and fashion education: adventures on the green. Journal of Sustainability Education 4.

13. Williams D (2016) Engaging stakeholders in education for sustainable development at university level. Transition to Transformation in Fashion Education for Sustainability, London.

14. Fletcher K, Williams D (2013) Fashion education in sustainability in practice. Research Journal of Textile and Apparel 17(2): 81-88.

Creative Commons Attribution 4.0

International License

For possible submission use the below is the URL
15. Wals AEJ, Rodela R (2014) Social learning towards sustainability: problematic, perspectives and promise. In: NJAS - Wageningen Journal of Life Sciences 69: 1-3.

16. Ehrenfeld J (2008) Sustainability by design. A subversive Strategy for Transforming Our Consumer Culture. New Haven, USA.

17. Geiger SM, Otto S, Schrader U (2017) Mindfully green and healthy: An indirect path from mindfulness to ecological behaviour. Frontiers in Psychology 8: 2306.

18. Orr D (1992) Ecological literacy. Education and the Transition to a Postmodern World, New York, USA

19. Barth M, Adomßent M, Fischer D, Richter S, Rieckmann M (2014) Learning to change universities from within: A service-learning perspective on promoting sustainable consumption in higher education. Journal of Cleaner Production 62: 72- 81

\section{Your subsequent submission with Crimson Publishers} will attain the below benefits

- High-level peer review and editorial services

- Freely accessible online immediately upon publication

- Authors retain the copyright to their work

- Licensing it under a Creative Commons license

- Visibility through different online platforms

- Global attainment for your research

- Article availability in different formats (Pdf, E-pub, Full Text)

- Endless customer service

- Reasonable Membership services

- Reprints availability upon request

- One step article tracking system 